\title{
Seasonal and geographical differences in cleaner fish activity in the Mediterranean Sea
}

Received: 17 January 2001 / Received in revised form: 10 August 2001 / Accepted: 10 August 2001 / Published online: 11 October 2001 C) Springer-Verlag and AWI 2001

\begin{abstract}
Investigations into symbioses may be important in order to analyse the grade of stability in ecosystems. Host-cleaner relationships were investigated in two localities of the Mediterranean Sea: Giglio (Tuscany, Italy) and Banyuls-sur-Mer (France). The cleaner wrasse, Symphodus melanocercus, was the main cleaner. Supplementary cleaners, such as the young of several wrasses, Symphodus mediterraneus, Symphodus ocellatus, Symphodus tinca, Coris julis and Ctenolabrus rupestris, are able to help out in times when there is a shortage of cleaners. Differences between the localities were obvious by a greater fish (host) density in Banyuls, which is probably due to eutrophication and might improve and increase cleaner activities. Regarding two seasons, spring and late summer, the fishes presented a lower degree of activity in Giglio, but a higher one in Banyuls in late summer compared with spring. The main hosts were Chromis chromis, Symphodus tinca and Coris julis; additionally Diplodus sargus in Banyuls and Apogon imberbis in Giglio. Chromis chromis may be a key host species because of its distribution in large groups in the whole Mediterranean; Coris julis is of similar abundance. Symphodus melanocercus additionally came into contact with Symphodus tinca in order to partake of the food of the peacock wrasse. During cleaning activities, Diplodus sargus and other sparids present hesitant behaviour, where the cleaner probably picks more than parasites (skin, scales?) from the body surface. Apogon imberbis (which prefers dark habitats such as caves) totally rejects the main cleaner but was cleaned exclusively by Coris julis which, unlike Symphodus melanocercus, is regularly present near cave entrances. The investigations may present models of the evolutionary processes on specialised partnerships in ecosystems.
\end{abstract}

Communicated by: H.-D. Franke

C.D. Zander ( $\left({ }^{-}\right) \cdot$ I. Sötje

Zoologisches Institut und Zoologisches Museum,

Universität Hamburg, Hamburg, Germany

e-mail: cedezet@zoologie.uni-hamburg.de

Tel.: +49-40-428383876, Fax: +49-40-428383937
Keywords Cleaner wrasse - Symphodus spp. Symbiosis $\cdot$ Mediterranean Sea $\cdot$ Cleaner activity

\section{Introduction}

Cleaner fish symbioses are widespread in the sea and maybe in fresh water as well (Losey et al. 1999; Zander et al. 1999). This mode of symbiosis represents either facultative or obligatory mutualism, or even a type of parasitism. In the tropic Indo-Pacific the labrid Labroides dimidiatus is an obligatory cleaner fish, whose territories become cleaner stations (Randall 1958); at other localities different fish species can play this role, for instance, the labrid Oxyjulis californicus on the American west coast (Hobson 1971), the gobiid Elacatinus oceanops in the Caribbean (Eibl-Eibesfeldt 1955), and the labrid Symphodus melanocercus in the Mediterranean (von Wahlert and von Wahlert 1961; Heymer 1972). Three labrids may function as cleaners in the temperate NE Atlantic: Ctenolabrus rupestris, Symphodus melops and Centrolabrus exoletus (Costello 1991). If several cleaner fish species co-occur, these may play the role either of main or of complementary cleaners (Zander and Nieder 1997).

The advantage for the cleaner is in getting an easily attainable prey from a living substrate (the host) which may approach the cleaner in order to become free of parasites. When host density is high, parasites, especially copepods and isopods (Senn 1979; Gorlick et al. 1987), are sufficient prey for cleaner fish. In other cases, cleaners are forced to search for additional food. This additional food can consist of planktonic or benthic organisms but can also be skin and scales from the host (Losey 1972, 1987). This kind of parasitism can also be observed as the only way of foraging in some cleaner mimics, such as the blenny Aspidontus taeniatus (Eibl-Eibesfeldt 1959).

Symphodus melanocercus, supported or substituted by several other labrid species, is the main cleaner fish in the Mediterranean (Zander et al. 1999). Where Symphodus melanocercus is absent, especially in the 
eastern Mediterranean, young Thalassoma pavo play an increasingly important part as cleaners (Moosleitner 1980), whereas this species is not present in the colder NW Mediterranean. Symphodus melanocercus males have permanent territories which function as cleaning stations, but in contrast to other Symphodus species, they do not care for their spawn (Almada et al. 1999).

Our investigations into cleaner symbioses were focused on localities in the western Mediterranean: Banyuls-sur-Mer (Golf du Lion, France) and the Isle of Giglio (Tyrrhenian Sea, Tuscany, Italy) (Zander and Nieder 1997; Zander et al. 1999). The aim of the present study was to find out whether these two localities might differ in the number of cleaner species involved, in cleaning activities and, additionally, in the possible influence of different seasons. Special attention was paid to the feeding behaviour of the cleaner wrasse Symphodus melanocercus and to possible preferences and specialisations between cleaner and hosts.

\section{Materials and methods}

The study was performed in two localities of the western Mediterranean Sea: Banyuls-sur-Mer (Golf du Lion, France) in June 1999 and the island of Giglio (Tuscany, Italy) in September 1999. Former studies at Giglio in June 1994 (Zander and Nieder 1997) and at Banyuls in September 1996 (Zander et al. 1999) are included in order to compare seasonal influences at the two localities. The observations were performed with the help of SCUBA in water depths of 9-16 m. The habitat at Ile Grosse off Banyuls is dominated by rocks with steep walls which rise 3-8 $\mathrm{m}$ above the bottom. The gaps between the walls are filled with pebbles and smaller boulders or sand (Zander 1996). The rocks are overgrown by calcareous algae which build, especially in shadowy places, the "coralligene": an underwater formation consisting of many caves ranging from small to tiny. The habitat of "Tralicce 3" off Giglio Campese is built up by a disused ore-shipping installation with a stone base of $10 \mathrm{~m}^{2}$ which extends down to a sandy bottom, ranging from $9 \mathrm{~m}$ (coastside) to $15 \mathrm{~m}$ (seaside) (Zander and Nieder 1997). The stone base is made of large blocks, now partly missing and allowing access to caves in the interior. The foot of the base is covered by boulders, and debris creates a richly structured habitat with many small caves.

Benthic and suprabenthic fish in depths of 9-15 m were estimated visually according to four classes of abundance: $1=$ rare (1 specimen or fewer per $50 \mathrm{~m}^{2}, 2=$ moderate $(2-5), 3=$ common $(6-20)$, and $4=$ numerous $\left(>20\right.$ specimen per $\left.50 \mathrm{~m}^{2}\right)$. The activities of cleaners and hosts were observed during 24 (Banyuls) and 23 (Giglio) temporal units of 5 min each. Every contact, posing of hosts, approach to hosts by cleaners, cleaner picking on hosts, on substrate or on ejaculates of other labrid species as well as other behavioural activities, were recorded on a plastic slate.

The data were evaluated with the usual statistical parameters and tests such as mean $(x)$ and standard deviation $(\sigma)$, mean error $(m)$, variance analysis $(F)$, Students test $(t)$, correlation coefficient for regressions $(r)$ and test for homogeneity $\left(\chi^{2}\right)$.

\section{Results}

Feeding activities of Symphodus melanocercus

The analysis of the feeding behaviour of Symphodus melanocercus during the 5 min observation units reveals

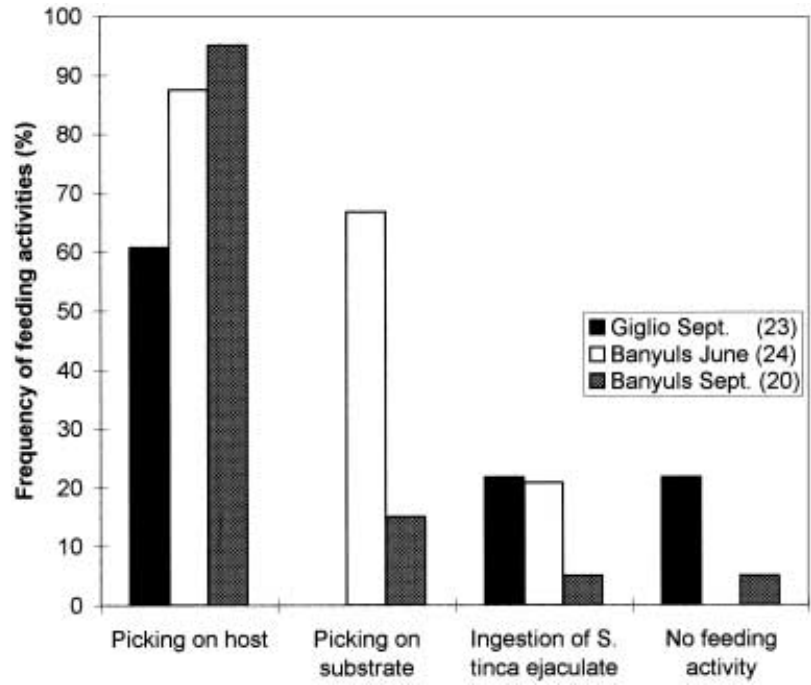

Fig. 1 Frequency of feeding activities of Symphodus melanocercus with comparison at two localities and two different times. Because all three kinds of feeding can occur during a 5-min observation unit, the sum of frequencies can attain more than $100 \%$. Numbers in parentheses are observation units of $5 \mathrm{~min}$

that picking on hosts was the most frequent activity at both localities (Fig. 1). Picking on the substrate was frequent only at Banyuls, whereas persuading Symphodus tinca and ingestion of ejaculates of this species played a minor role at that locality. A minority of cleaner fish did not show any feeding activity at Banyuls in late summer. Many of the cleaner wrasse from Giglio fed on the ejaculates of Symphodus tinca, but a similar number did not feed at all. An analysis of variance showed that the rows of values were homogeneous $[F(2,9)=0.24$; $P<0.05]$.

Generally, hosts were more frequently approached in Banyuls in spring than they were in summer, and more frequently in Banyuls than they were in Giglio. The number of approached host individuals per $5 \mathrm{~min}$ ranged from 7.3 to 9.8 at Banyuls and from 2.6 to 4.1 at Giglio. The numbers of cleaner pickings were about 12 in Banyuls and 2-2.5 in Giglio (Fig. 2). The fluctuations of host numbers of the respective spring and summer values did not differ significantly, whereas values from Banyuls and Giglio clearly do $(\mathrm{m} / \mathrm{m}$ diff $>3)$. The pattern of picking per $5 \mathrm{~min}$ is similar, differing between localities $(\mathrm{m} / \mathrm{m}$ diff $>3)$ but not between seasons. The number of approached host species, however, did not differ to the same extent as the other parameters. Significant differences occurred at Giglio between spring and summer $(\mathrm{m} / \mathrm{m}$ diff $>3)$, and between Giglio and Banyuls in summer $(m / m$ diff $>3)$.

Figure 3 shows the frequencies of approaches to single host species. Symphodus tinca, Coris julis and Chromis chromis were the most frequently approached host species. Additional hosts were Diplodus sargus in Banyuls and Apogon imberbis in Giglio. An analysis revealed that variances with respect to both seasons and localities were homogeneous $[F(57,18)=0.11 ; P<0.05]$. 
Fig. 2 Activities of the cleaner wrasse, Symphodus melanocercus. Mean numbers of approached host individuals, approached host species and picking on hosts within the observation time of 5 min. $x$ mean, $s$ standard deviation

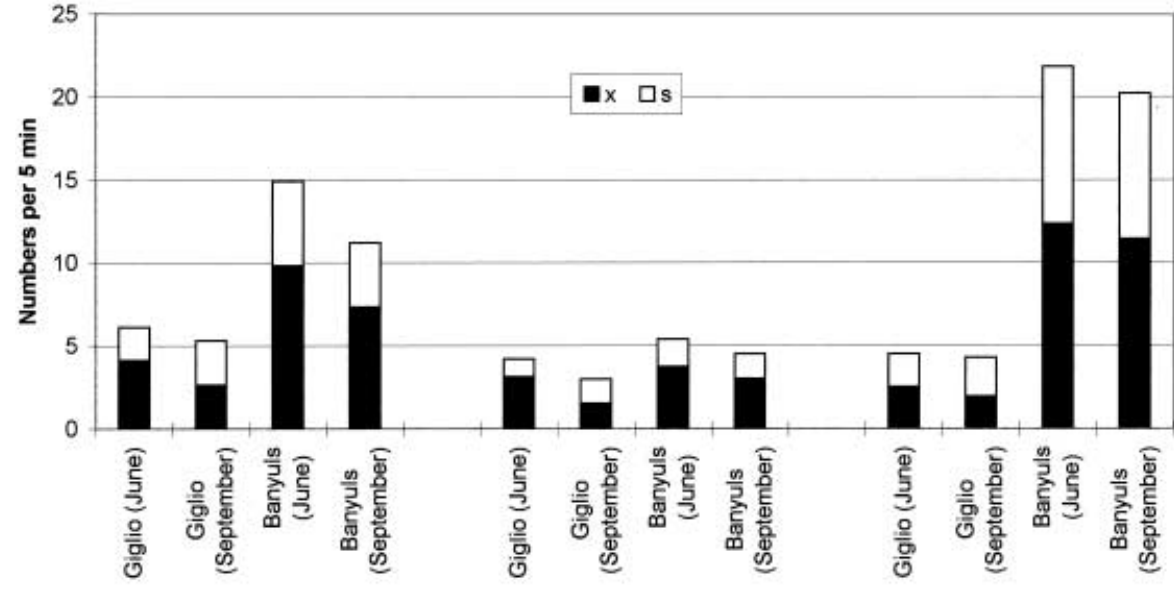

Approached host individuals Approached host species

Cleaner pickings

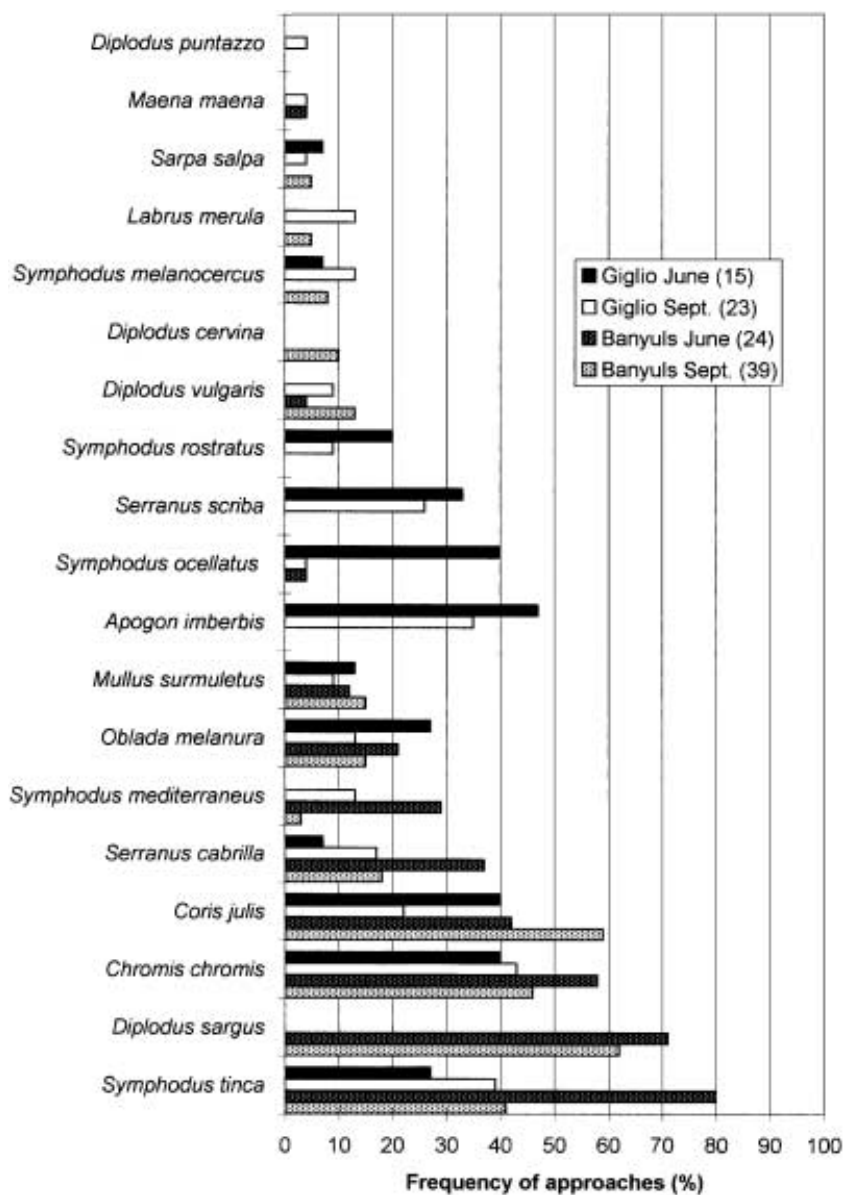

Fig. 3 Frequency of approaches by Symphodus melanocercus to 19 host species at two localities and two different times of the year. Numbers in parentheses are observation units of $5 \mathrm{~min}$

\section{Host preferences of Symphodus melanocercus}

The number of observed host species in the investigation areas was generally about 25, except for Giglio in summer when 36 species were observed (Table 1). Some species showed clear local differences in abundance. Diplodus sargus was rare in Giglio, while Apogon imberbis was absent in the investigated habitat off Banyuls. Furthermore, the labrid Ctenolabrus rupestris, which only occasionally cleaned, was present solely in Banyuls; Thalassoma pavo and Symphodus doderleini occurred only in Giglio. Rare species may have been overlooked during the investigations.

The regression of host abundance to the frequency of approaches or picking by Symphodus melanocercus showed different results. The frequency of approaches was mostly positively correlated with the fish abundance while, on the other hand, the frequency of pickings was mainly not. Both values, approaches as well as pickings, were not correlated from Giglio in spring, which indicates a preference for distinct hosts (approaches vs picking: $r=0.55$ vs $0.47, d f=10, P>0.05$ ) (Fig. 4a). The other three cases reached significance for potential fish species both those present and those approached, but the picking frequency was not correlated in Giglio in summer ( $r=0.72$ vs $0.47, d f=15, P<0.005$ vs $>0.05$ ); or in Banyuls in spring ( $r=0.85$ vs $0.55, d f=11$, $P>0.001$ vs $>0.05$ ). The shallow regression line indicated a reduction in the success of cleaning (Fig. 4b, c). In summer, the Banyuls fish guilds seemed to be cleaned in accordance with their abundance (for both: $r=0.93$, $d f=11, P<0.001)$ (Fig. 4d).

The success of cleaning by Symphodus melanocercus differed from host to host, following approaches made to them (Fig. 5). In general, the success of cleaning was

Fig. 4a-d Host abundances at two localities and at two different times of the year correlated to the frequencies of approached host species (thick line), and of picking by Symphodus melanocercus (thin line). Solid lines indicate significant correlation, broken lines indicate no significant correlation. Abundance categories: 1 rare, 2 moderate, 3 common, 4 numerous (see Table 1). a Correlation of values from Giglio in June, b correlation of values from Giglio in September, c correlation of values from Banyuls in June, $\mathbf{d}$ correlation of values from Giglio in September 
Table 1 Abundances of potential fish hosts at two localities in the Mediterranean in June and September. Categories of abundance: 1 rare (1 or less specimen), 2 moderate (2-5), 3 common (6-20), 4 numerous (more than 20 specimen per $50 \mathrm{~m}^{2}$ )

\begin{tabular}{|c|c|c|c|c|c|c|c|c|c|}
\hline \multirow[t]{2}{*}{ Species } & \multicolumn{2}{|c|}{ Giglio } & \multicolumn{2}{|c|}{ Banyuls } & \multirow[t]{2}{*}{ Species } & \multicolumn{2}{|c|}{ Giglio } & \multicolumn{2}{|c|}{ Banyuls } \\
\hline & June & Sept & June & Sept & & June & Sept & June & Sept \\
\hline Symphodus melanocercus & 2 & 3 & 2 & 2 & Chromis chomis & 4 & 4 & 4 & 3 \\
\hline Symphodus tinca & 2 & 3 & 4 & 3 & Apogon imberbis & 3 & $3-4$ & & \\
\hline Symphodus rostratus & 2 & 3 & & & Serranus scriba & 1 & 2 & & \\
\hline Symphodus mediterraneus & 3 & 2 & 3 & 2 & Serranus cabrilla & 2 & 2 & $2-3$ & 2 \\
\hline Symphodus ocellatus & 3 & 2 & 2 & 2 & Epinephelus guaza & 1 & 1 & & \\
\hline Symphodus roissali & 1 & 1 & & & Anthias anthias & 2 & & & \\
\hline Symphodus doderleini & 2 & 2 & & & Muraena helena & & 1 & & \\
\hline Ctenolabrus rupestris & & & 2 & 2 & Conger conger & & 1 & 1 & 2 \\
\hline Thalassoma pavo & 2 & 2 & & & Scorpaena porcus & 2 & 2 & & \\
\hline Coris julis & 2 & $3-4$ & 4 & 4 & Scorpaena scrofa & & 1 & 1 & 1 \\
\hline Labrus merula & & 1 & & 1 & Scorpaena notata & & 1 & & \\
\hline Sarpa salpa & 1 & 2 & 1 & 1 & Parablennius rouxi & 2 & 1 & 2 & 3 \\
\hline Boops boops & & 1 & & & Parablennius gattorugine & & 1 & & \\
\hline Oblada melanura & & 2 & 2 & 2 & Parablennius pilicornis & & & 1 & 1 \\
\hline Sparus auratus & & & 1 & 1 & Lipophrys nigriceps & 2 & & & \\
\hline Dentex dentex & & & 1 & & Tripterygion delaisi & 1 & 1 & 1 & 2 \\
\hline Diplodus vulgaris & 1 & 2 & 2 & 2 & T. melanurus & 2 & & 1 & \\
\hline Diplodus puntazzo & & 1 & & & Synodus saurus & & 1 & & \\
\hline Diplodus sargus & & 1 & 4 & 4 & Gobius geniporus & 4 & 2 & & \\
\hline Diplodus cervinus & & & 1 & 1 & Gobius vittatus & & 1 & & 1 \\
\hline Spondylosoma cantharus & & & 1 & & Gobius xanthocephalus & & & 1 & 1 \\
\hline Spicara maena & & & 1 & 1 & Thorogobius ephippiatus & 1 & 1 & & \\
\hline Mullus surmuletus & 2 & 1 & 3 & 2 & Hippocampus ramulosus & & 1 & & \\
\hline & & & & & Number of species & 25 & 36 & 25 & 24 \\
\hline
\end{tabular}

Giglio (June)

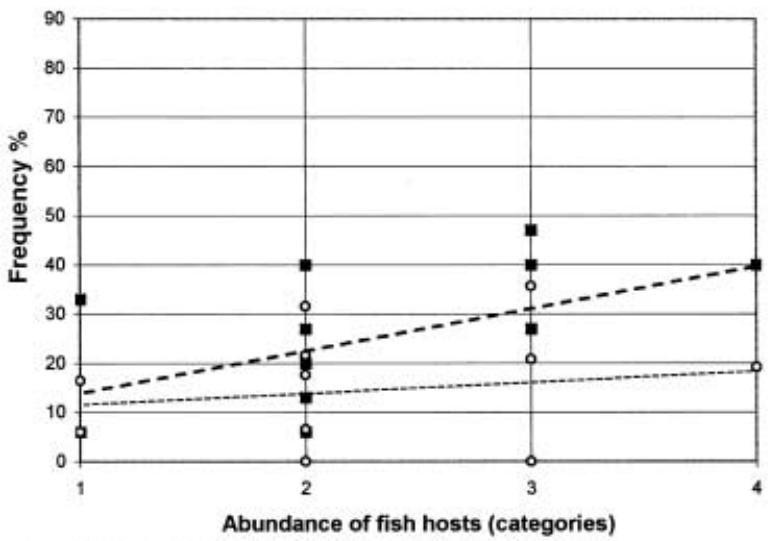

a - Frequency of approaches o Frequency of pickings

Banyuls (June)

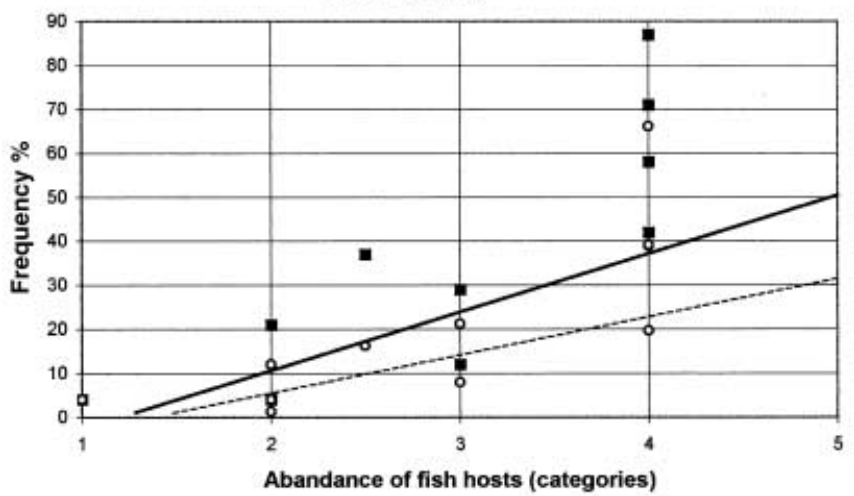

C
Giglio (September)

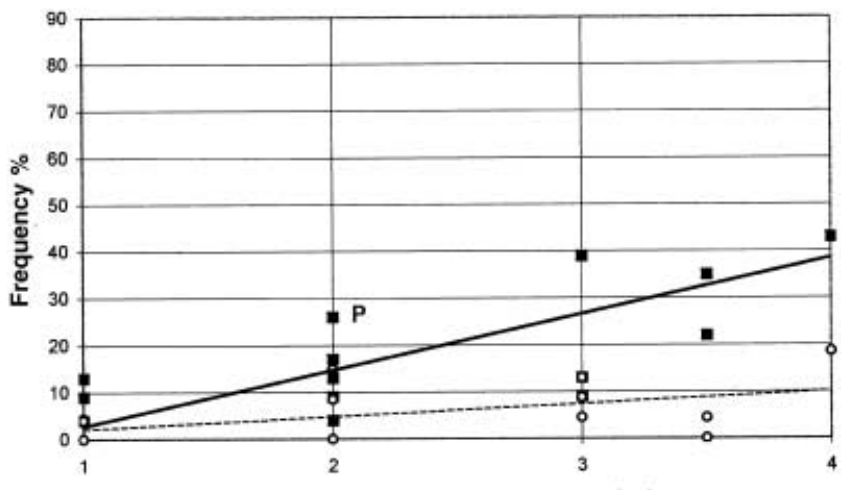

Abundance of fish hosts (categories)

b Frequency of approaches of Frequency of pickings

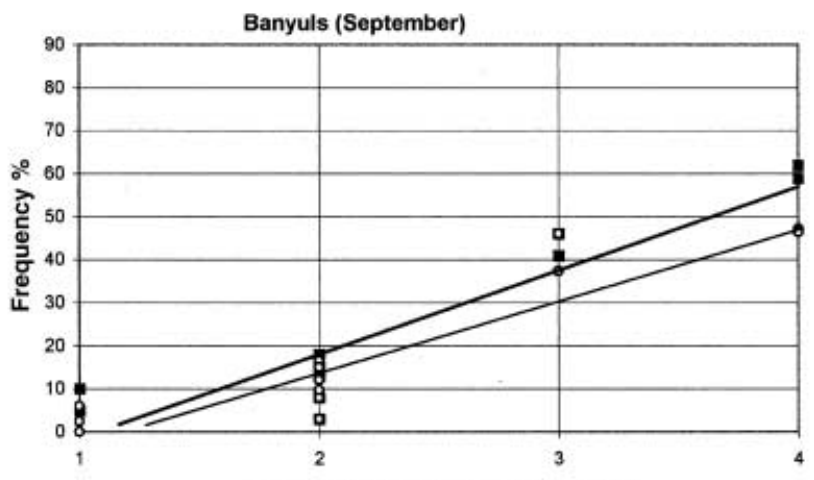

Abundance of fish hosts (categories)

d 
Fig. 5 Parts of cleaning success and failure of Symphodus melanocercus after contact to 10 host species in two localities and in two different times of the year

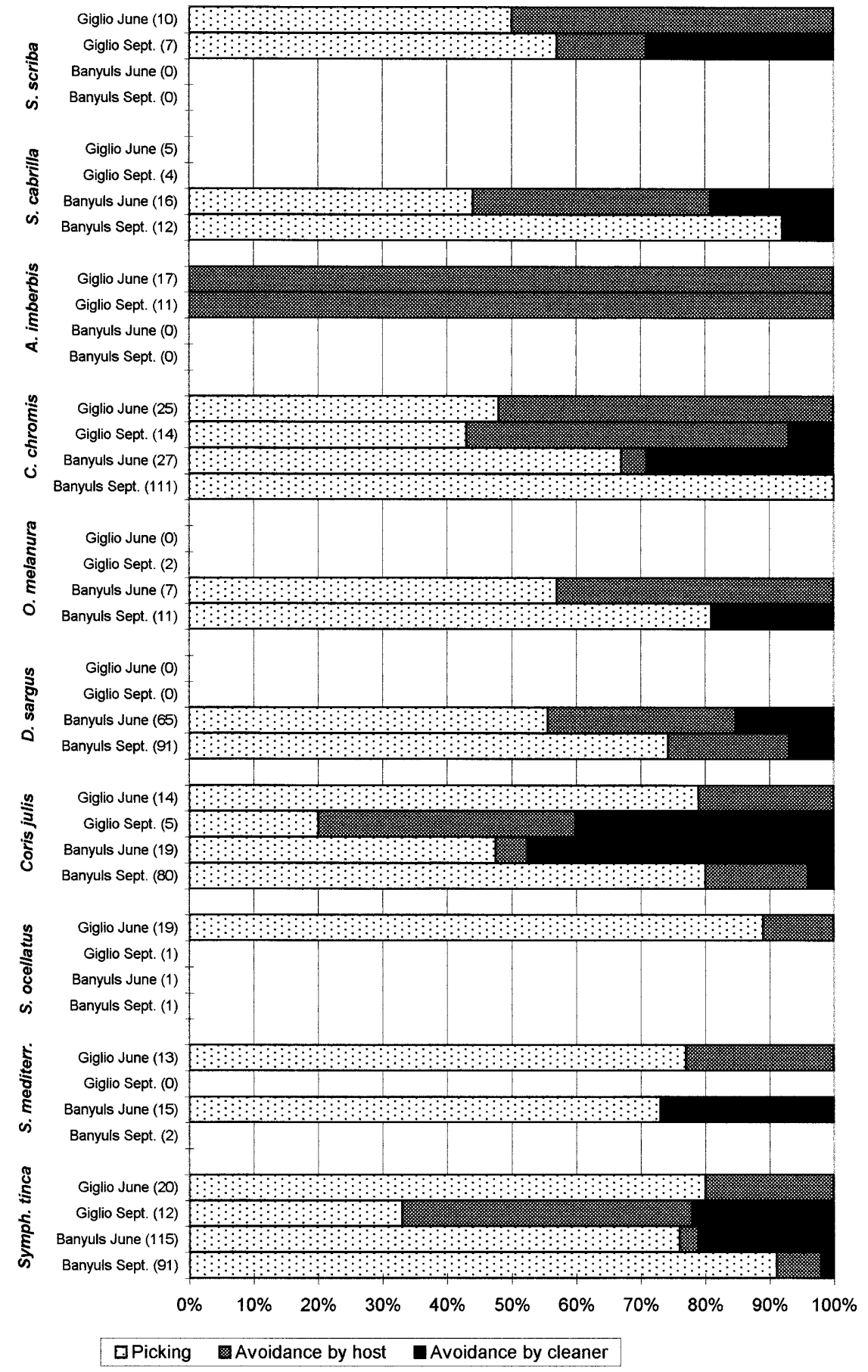

higher in Banyuls than in Giglio $(t=2.58, d f=3, P<0.05)$. In the most cases of avoidance the hosts were not ready to be cleaned, Apogon imberbis even rejected Symphodus melanocercus totally. Chromis chromis, Serranus scriba and Symphodus tinca also avoided approaching cleaner wrasses to a greater degree in Giglio. However, posing hosts were also avoided by Symphodus melanocercus, in particular Coris julis but additionally Serranus scriba or Chromis chromis (Fig. 5). Nevertheless, greater success (>80\%) was evident in hosts such as Serranus cabrilla, Chromis chromis, Oblada melanura,
Coris julis, Symphodus ocellatus or, at certain times, Symphodus tinca.

The quantitative analysis of approaches and picking of single host species revealed topical differences at both localities (Fig. 6a, b). Generally, these values were higher in Banyuls than in Giglio, with the exception of approaches to Chromis chromis in spring. A second apparent difference is that the picking values in Banyuls are usually higher in summer, but in Giglio they are higher in spring. Only Symphodus mediterraneus in Banyuls and, to a lesser extent, Serranus scriba in Giglio, dis- 
Fig. 6a, b Comparison of values from June and September regarding the number of approaches per $5 \mathrm{~min}$ and of picking per host. a Locality of Giglio, Italy, b locality of Banyuls, France

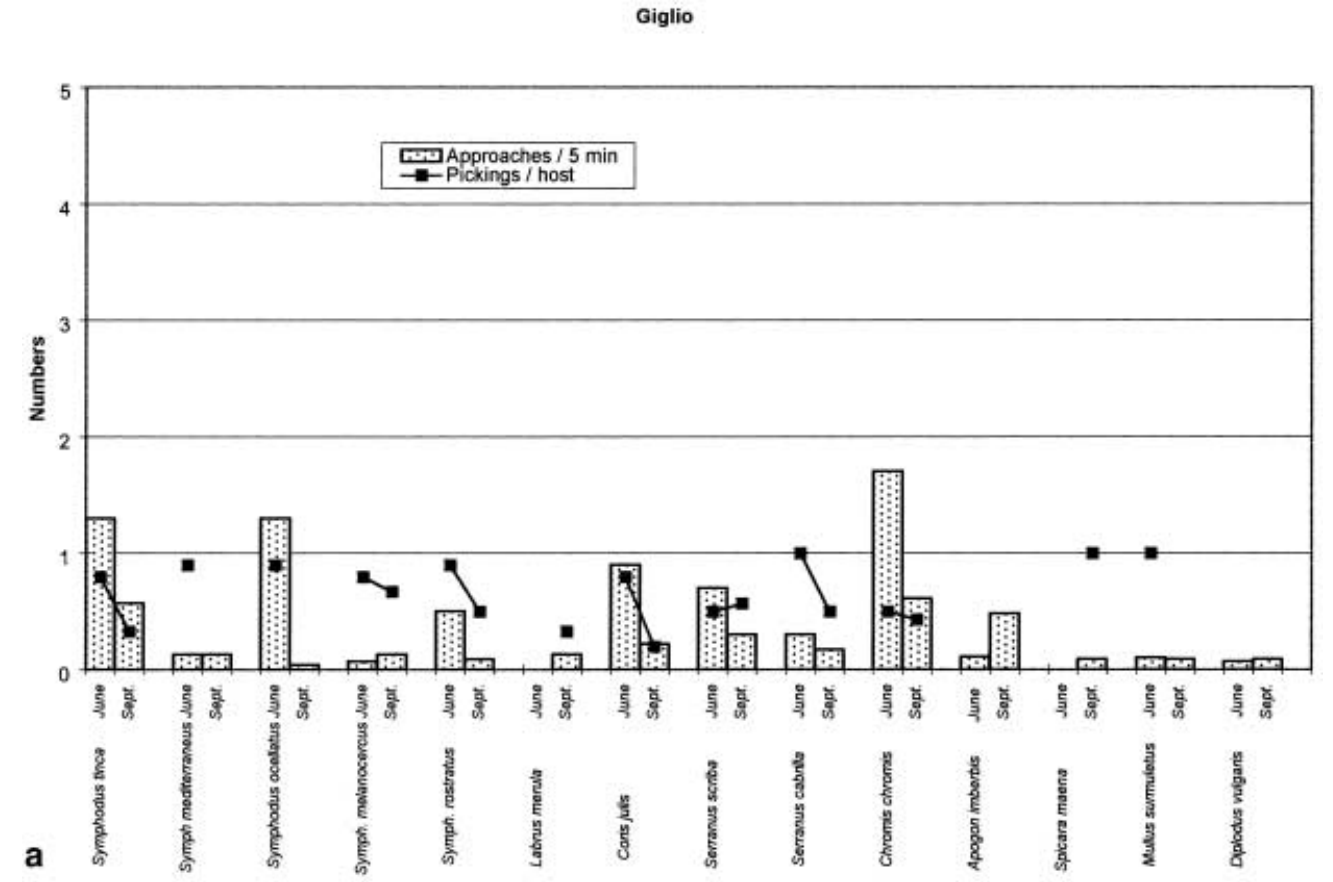

Banyuls

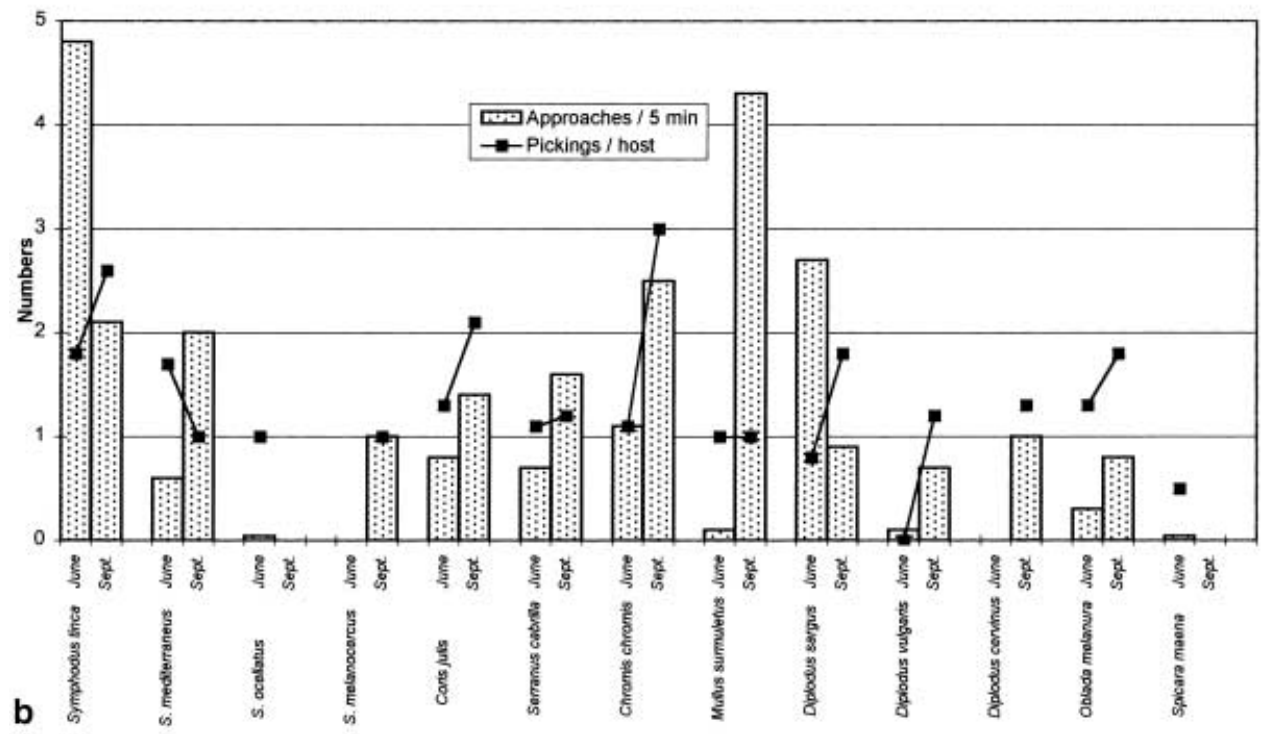

played the opposite trend. The differences between seasons were significant in Giglio (approaches: $t=2.6$, $d f=11, P<0.05$; pickings: $t=3.4, d f=6, P<0.01)$. In Banyuls, however, the seasonal differences of approaches were not significant because the values of the most frequently persuaded hosts, Symphodus tinca and Diplodus sargus, were the inverse of those of the other hosts $(t=0.9, d f=8, P>0.1)$. The increase in picking values from spring to summer was also significant $(t=2.4, d f=8$, $P<0.05)$.
Complementary cleaner

A low level of activity of complementary cleaners such as Coris julis, Symphodus ocellatus females, Symphodus tinca juveniles and Symphodus mediterraneus (once only) was observed in Giglio. A compilation of spring and summer values presents the great success of these cleaners - as much as $100 \%$ in the case of Coris julis and the speleobiont host Apogon imberbis (Fig. 7). The result differed from that of Symphodus melanocercus, which was totally avoided by Apogon imberbis (Fig. 5). Both cleaners used different ways approaching this host: 
Fig. 7 Ratios of cleaning success and failure of three supplemental cleaner species in Giglio from June 1994

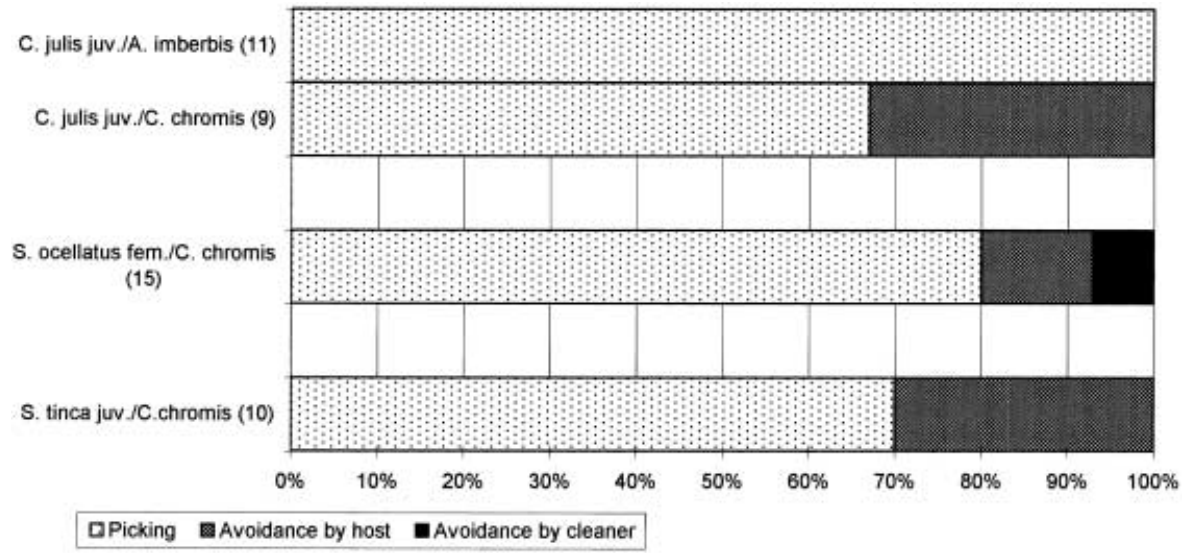

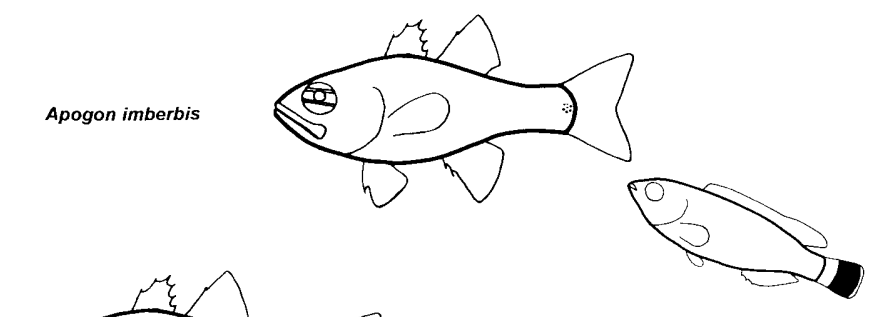

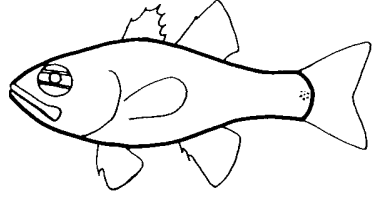

Symphodus melanocercus
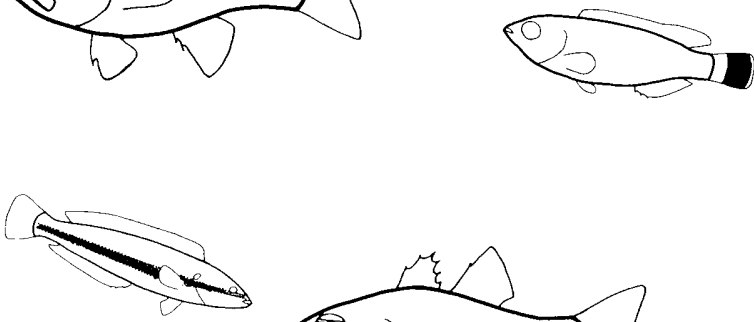

Coris julis juv.
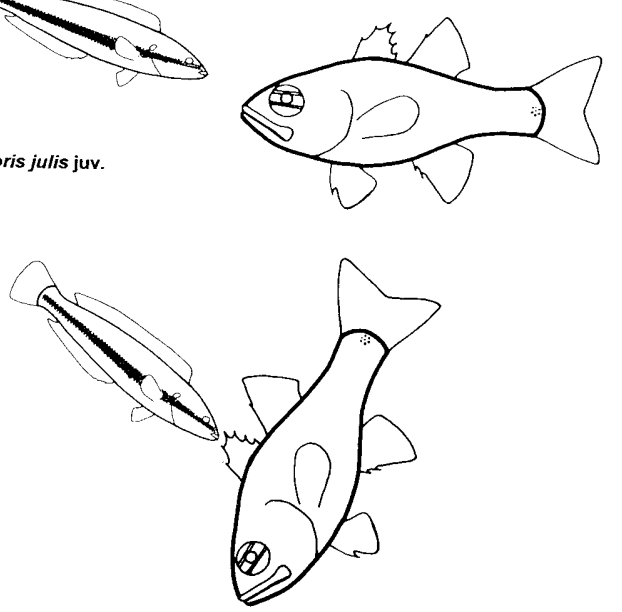

Fig. 8 Different behaviours of the cleaner species Symphodus melanocercus and Coris julis approaching the host Apogon imberbis, which reacts differently

Symphodus melanocercus always swims from behind onto the tail; Coris julis appears in front of the head of the cardinal fish (Fig. 8). The variance analysis of success and avoidance was, in four partnerships, homogeneous $[F(11,8)=0.75 ; P<0.05]$.

Complementary cleaners were less active in Banyuls than in Giglio. Notable are Coris julis, which either cleaned larger conspecifics or Chromis chromis, and Ctenolabrus rupestris, which cleaned conspecifics and Coris julis, sometimes together with Symphodus melanocercus. Chromis chromis also posed before the goldsinny, but without success.

Posing positions of hosts and special behaviour of cleaner

The posing positions from all observations are compiled in Fig. 9. Apogon imberbis always posed straight downwards before Coris julis. A great variety of positions were presented by the labrids Symphodus tinca, which preferred to pose downwards, and Symphodus mediterraneus with nearly equal occurrences of upward and downward positions. All hosts displayed very heterogeneous positions. Diplodus sargus posed mostly downwards, Chromis chromis and Coris julis mostly upwards. Unexpectedly, Mullus surmuletus only presented a straight upward position in Giglio in summer 1999, whereas formerly and also in Banyuls, only a horizontal position had been observed. Remarkably, the two Serranus species clearly differ in preferring either the horizontal (Serranus cabrilla) or the inclined upward position (Serranus scriba) (Fig. 9). $\chi^{2}$-tests as regards all positions demonstrated inhomogeneity for all hosts $(P<0.001)$, but comparisons between upward or downward positions of Diplodus sargus and Symphodus mediterraneus were homogeneous $(P>0.05)$.

The extreme straight upward or straight downward positions were found in Chromis chromis and the labrid species in high ratios. All Apogon imberbis were positioned straight downward, whereas the other species showed rather different positions (Fig. 9).

A special behavioural trait was observed in Symphodus melanocercus: a manifold turning around the longitudinal axis in a horizontal position. Its proportion within the 5-min standard units was $16 \%$ (spring) and $10 \%$ (summer) in Banyuls, 4\% (summer; no data from spring) in Giglio. A similar movement, but in a vertical position, was displayed when males were courting in front of females. 
Fig. 9 Ratios of different posing positions of 12 host species combined from both localities, Giglio and Banyuls, and both seasons, June and September

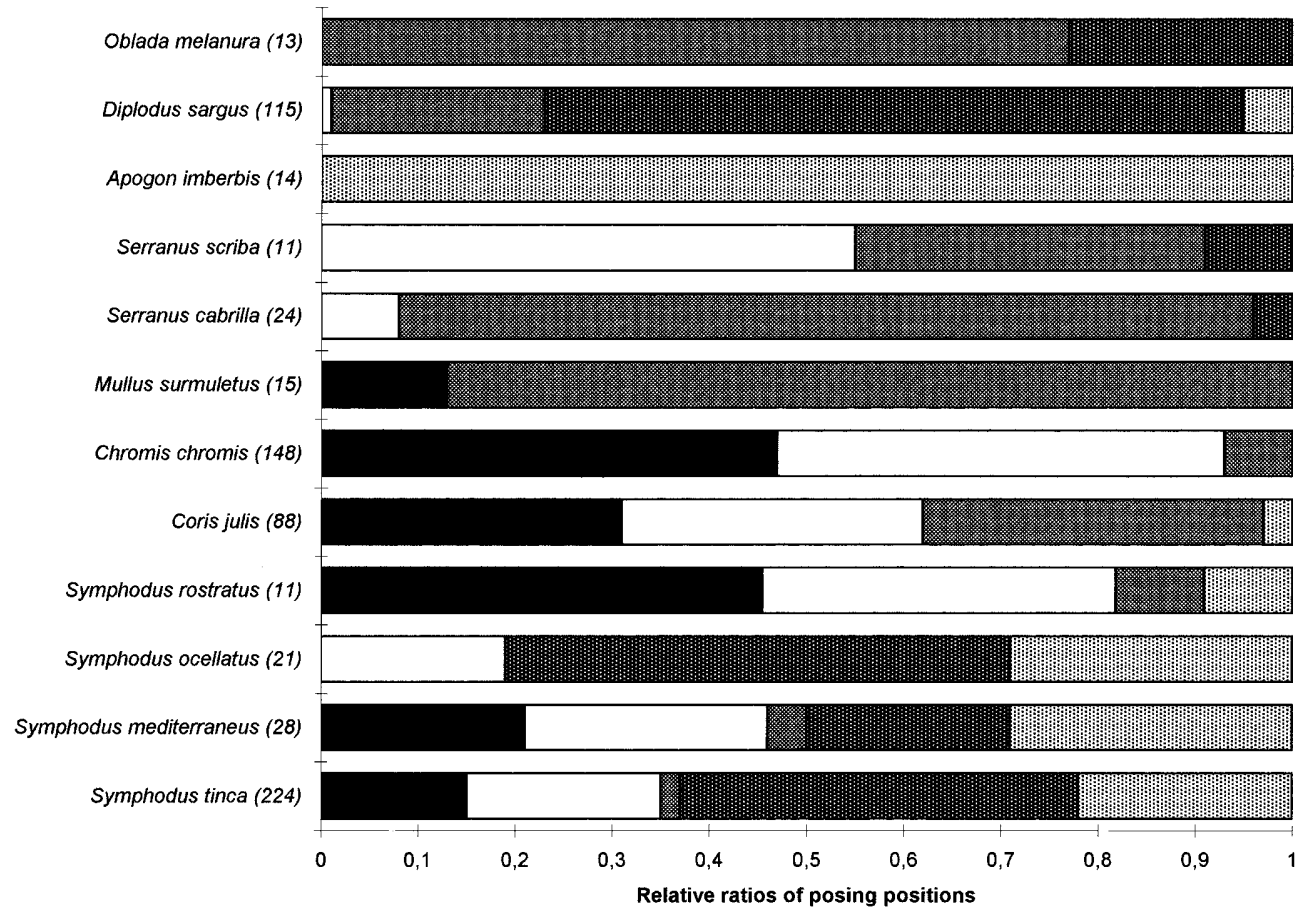

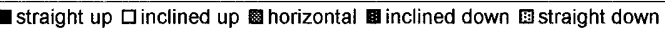

\section{Discussion}

Topical and seasonal differences

Reports on cleaner symbiosis in the Mediterranean reveal several geographical differences (Moosleitner 1980; Zander and Nieder 1997; Zander et. al. 1999). In many areas Symphodus melanocercus plays the dominating role within the cleaner guild and is called the main cleaner, whereas other labrids which only occasionally clean are called complementary cleaners (Zander and Nieder 1997). A large number of Symphodus melanocercus spend most of the time involved in cleaner activities but also ingest additional prey from the substrate in Banyuls, especially in spring, as do other labrid species. This behaviour was not observed in Giglio despite the cleaning activity being lower there.

Regarding the possible host spectrum and their densities, fish communities in the shallow Mediterranean can comprise as many as 52 species (Abel 1962). In summary, of the number of species from the respective spring and summer investigations, 38 fish species were found in Giglio and 26 in Banyuls. The fish community of Giglio was probably richer because the habitat was more diversely structured through the existence of caves of different sizes. Chromis chromis, Symphodus tinca and Coris julis were the main hosts, and, additionally, Diplodus sargus in Banyuls, and Apogon imberbis in Giglio. Chromis chromis appears very frequently elsewhere in the Mediterranean - as was observed off Naples (Italy) (Abel 1962), Chalkidike (Moosleitner 1980), Crete (Greece), Malta, Mallorca (Spain) and Adria, off
Dubrovnik (Croatia) (Zander and Nieder 1997; C.D. Zander, unpublished). Therefore, this species might present a rich source of parasites overall which, in turn, could attract cleaning activities. The number of approaches of Symphodus melanocercus to Chromis chromis was unexpectedly lower in Banyuls in springtime than in Giglio, obviously due to the breeding activities of this host which were seen to often chase the cleaner away from their nests (see also Abel 1961). Thus, the compensation for the lower availability of Chromis chromis at this time may be the reason for the increase in numbers approaching Symphodus tinca and Diplodus sargus in spring; this was in opposition to the general trend in Banyuls: higher values in summer than in spring to most of the hosts (Fig. 6b). This trend seems to be plausible, as a consequence of better availability of most fish hosts after the breeding season. This is underlined by the higher picking numbers with respect to Symphodus tinca and Diplodus sargus in summer, when approaches to these species are lower. Unexpectedly, the inverse situation was found in Giglio, where the number of approaches as well as the number of pickings were even lower in summer than in spring (Fig. 6a). This was also clearly reflected by the respective success of cleaner activity of Symphodus melanocercus in these two localities and seasons. The reasons for these differences are not yet clear: a somewhat reduced infestation by parasites may be a possible cause.

Generally, the density of hosts was lower at Giglio than at Banyuls, with the exception of Chromis chromis, apparently due to the lower productivity in this part of the Mediterranean (Estrada et al. 1985). This was obvi- 
ous from the different depths of sight in Giglio $(20 \mathrm{~m}$ and more) and in Banyuls (5-10 m). Therefore, it is consistent that the number of hosts approached and the number of cleaner pickings are higher in Banyuls. The decrease in these values is less important in late summer, as is the decline in the number of approached host species, which was actually similar in both localities in spring. In contrast, the rare occurrence of sparids was conspicuous in Giglio: Diplodus sargus, one of the most abundant species in Banyuls, was only found by single specimen. This may be the result of a richer supply of benthic algae, which is needed as food by young sparids in Banyuls (Bauchot and Hureau 1986).

In spite of lower host density, the number of successful approaches was also lower in Giglio. This may result from lower infestation by ectoparasites in this area, which probably causes the cleaner wrasse to ingest larger amounts of food from the substrate. But this assumption does not agree with our results, because only feeding on ejaculates of Symphodus tinca, and no substrate feeding, was observed. The reason for the relatively high proportion of non-feeding Symphodus melanocercus was probably due to the lack of observation at times when such feeding activities take place, maybe beginning at dawn. Another possibility may be occasional plankton feeding by this species. These assumptions need to be checked by observations throughout the day. Differences in feeding activities are also known from the Indo-Pacific cleaner wrasse Labroides dimidiatus from different localities (Grutter 1997).

\section{Specialisation of cleaner and hosts}

The approach and picking activities of Symphodus melanocercus can reveal some affinities to single host species. Most approach activities in the two investigated localities at different seasons were correlated with the abundance of potential hosts, but most picking activities were not. This indicates that the behaviour of the host clearly influences the cleaning success of the cleaner.

Zander and Nieder (1997) found that Symphodus melanocercus had lower success in Giglio than did the complementary cleaner species Symphodus tinca, Symphodus ocellatus and Coris julis. Complementary cleaning was rarely observed in Banyuls, and then mostly by Coris julis. As a consequence, the activities of Symphodus melanocercus might have resulted in a greater success in Banyuls than in Giglio; this success even increased from spring to summer. This is emphasised by the seasonal comparison of six hosts, including Chromis chromis, from both localities in which these activities increased from 68 to $100 \%$. In contrast, the reverse trend was found in Giglio by three hosts, Serranus scriba being an exception. Even Chromis chromis was rejected by the cleaner at a low ratio, which increased the total ratio to $55 \%$ in summer. However, probably only in combination with direct observations, are these results of success or of failure suited to the recognition of specialisations.
Apogon imberbis totally refused all approaches of Symphodus melanocercus, but tolerated all approaches by Coris julis which presented unambiguous situations. In this way, the results of Zander and Nieder (1997) were confirmed by a larger set of observations and are interpreted as the specialised association between cleaner and host. One such association may be caused by a more abundant presence of the rainbow wrasse near entrances of caves where Apogon imberbis lives. Another known specialisation from the Mediterranean and the eastern Atlantic area is that between shrimps and muraenids which were not cleaned by fishes (Moosleitner 1980; van Tassel et al. 1994). Coris julis is also involved in cleaning conspecifics and probably substitutes the often displayed avoidance of and by Symphodus melanocercus. Rainbow wrasse usually live together in groups of several numbers and of varying sizes and therefore may be easily reached by conspecific young.

Regarding sets of teeth, Symphodus melanocercus is better adapted for cleaning than other Symphodus species; and far better than other Mediterranean labrids including Coris julis (Casimir 1969). If we look at the sets of observations, Symphodus melanocercus is especially attracted to large species like Diplodus cervinus and Labrus merula and also to some middle-sized species like Mullus surmuletus and Serranus spp. (Zander et al. 1999). However, these hosts hesitated during approaches of the cleaner wrasse and, consequently, caused a high ratio of avoidance. In particular, the sparid species behaved very reservedly toward Symphodus melanocercus and often withdrew from the posing position if the cleaner came in contact; however, in many cases they reestablished the position again. The picking action seemed to be a painful one, because it mainly caused the sparid hosts to wince. They can probably be hurt by the pickings, as is known to be the case in Hawaiian cleaner fishes, Labroides phthiriophagus, which also feed on scales and mucus (Losey 1972, 1987).

A concept which takes into account the posing positions with their different slopes possibly explains the gradually diverse preferences of cleaners by their hosts. According to Casimir (1969) the degree of inclination indicates the appetitive behaviour, which is greater the steeper the slope is. According to this author, Symphodus melanocercus prefers the steeper-posing host to the others. Applied to the present investigation, seven hosts, including all Symphodus spp., displayed the extreme positions in around 33\%. Chromis chromis and Symphodus rostratus range about 50\%, Apogon imberbis even poses (only in front of Coris julis) exclusively with its head straight down. In contrast, Mullus surmuletus, Diplodus sargus, Oblada melanura and the Serranus spp. display the extreme positions only in very few instances or not at all. However, because the latter are the preferred host of Symphodus melanocercus, a coevolution cannot be acknowledged between them. In contrast, the association with Symphodus tinca is a very narrow one because the cleaner wrasse persuades the larger species in order to participate in the prey ejaculates and comes in close contact 
with the head of the larger species, where ectoparasites may be concentrated (Zander and Nieder 1997; Zander et al. 1999). Only two cleaning activities were performed on Symphodus tinca by Symphodus ocellatus females.

The role of Symphodus melanocercus is that of the main cleaner species in the Mediterranean. This is emphasised by special behaviour which is not observed in the complementary cleaner species: the manifold turning around the longitudinal axis (Zander et al. 1999). This behaviour could be derived from courtship behaviour. It is an advantageous releaser in order to attract the attention of potential hosts. In spite of all adaptations, Symphodus melanocercus is still far from being a professional cleaner like Labroides dimidiatus in the IndoPacific, whose source of food is exclusively ectoparasites (Grutter 1996). It is assumed that there may be a geographical cline from tropical to boreal regions where fishes with this role were only occasional cleaners (Zander et al. 1999). A similar situation to that in the Mediterranean may exist off the coast of California, where the labrid Oxyjulis californicus is the main cleaner. Additionally, there are also similarities in its colouring with that of the Mediterranean Symphodus melanocercus (Hobson 1971).

Acknowledgements We would like to thank Dr. Alain Guille and Jean-Claude Roca for laboratory and diving facilities at the Laboratoire Arago, Banyuls-sur-Mer, Dr. Claus Valentin and Holger Anlauf for the same kind of help at the Institute for Marine Biology, Giglio-Campese, Italy. Dr. Jürgen Nieder, Bodo Blume, Stefanie Bovensmann, Silvia Martin, Katharina Reichert and Maren Wellenreuther also helped to observe the cleaner activities in Giglio. Mrs. Andy Godfrey turned the text into readable English.

\section{References}

Abel EF (1961) Freiwasserstudien über das Fortpflanzungsverhalten des Mönchsfisches, Chromis chromis Linné, einem Vertreter der Pomacentriden im Mittelmeer. Z Tierpsychol 18:441-449

Abel EF (1962) Freiwasserbeobachtungen an Fischen im Golf von Neapel als Beitrag zur Kenntnis ihrer Ökologie und ihres Verhaltens. Int Rev Gesamt Hydrobiol 47:219-290

Almada VC, Henriques M, Gonçalves EJ (1999) Ecology and behaviour of reef fishes in the temperate north-eastern Atlantic and adjacent waters. In: Almada VC, Oliveira RF, Gonçalves EJ (eds) Behaviour and conservation of littoral fishes. Instituto Superior de Psicologia Aplicada, Lisbon, pp 33-69

Bauchot M-L, Hureau J-C (1986) Sparidae. In: Whitehead PJP, Bauchot M-L, Hureau J-C, Nielsen J, Tortonese E (eds) Fishes of the north-eastern Atlantic and the Mediterranean. Unesco, Paris, pp 883-907
Casimir MJ (1969) Zum Verhalten des Putzerfisches Symphodus melanocercus (Risso). Z Tierpsychol 26:225-229

Costello M (1991) Review of the biology of wrasse (Labridae: Pisces) in northern Europe: options and the use of cleaner fish. World Aquacult 24:49-56

Eibl-Eibesfeldt I (1955) Über Symbiosen, Parasitismus und andere besondere zwischenartliche Beziehungen tropischer Meeresfische. Z Tierpsychol 12:203-219

Eibl-Eibesfeldt I (1959) Der Fisch Aspidontus taeniatus als Nachahmer des Putzers Labroides dimidiatus. Z Tierpsychol 16:19-25

Estrada M, Vives F, Alcaraz M (1985) Life and the productivity of the open sea. In: Margalef R (ed) Western Mediterranean. Pergamon, Oxford, pp 148-197

Gorlick DL, Atkins PD, Losey GS (1987) Effect of cleaning by Labroides dimidiatus (Labridae) on an ectoparasite population at Eniwetok Atoll. Copeia 1987:41-45

Grutter AS (1996) Parasite removal rates by the cleaner wrasse Labroides dimidiatus. Mar Ecol Progr Ser 130:61-70

Grutter AS (1997) Spatio-temporal variation and feeding selectivity in the diet of the cleaner fish Labroides dimidiatus. Copeia 1997:346-355

Heymer A (1972) Ethologische Freiwasserbeobachtungen an Putzsymbiosen im Mittelmeer. Rev Comp Anim 6:17-24

Hobson ES (1971) Cleaning symbiosis among California inshore fishes. Fish Bull 69:491-528

Losey GS (1972) The ecological importance of cleaning symbiosis. Copeia 1972:820-833

Losey GS (1987) Cleaning symbiosis. Symbiosis 4:229-258

Losey GS, Grutter AS, Rosenquist G, Mahon JL, Zamzow JP (1999) Cleaning symbiosis: a review. In: Almada VC, Oliveira RF, Gonçalves EJ (eds) Behaviour and conservation of littoral fishes. Instituto Superior de Psicologia Aplicada, Lisbon, pp 379-395

Moosleitner H (1980) Cleanerfish and cleanershrimps in the Mediterranean. Zool Anz 205:219-240

Randall JE (1958) A review of the labrid fish genus Labroides, with description of two new species and notes on ecology. Pac Sci 12:327-347

Senn DG (1979) Zur Biologie des Putzerfisches Symphodus melanocercus (Risso). Senckenberg Marit 11:23-38

Tassel L van, Brito A, Bortone S (1994) Cleaning behavior among marine fishes and invertebrates in the Canary Islands. Cybium 18:117-127

Wahlert G von, Wahlert H von (1961) Le comportement de nettoyage de Crenilabrus melanocercus (Labridae) en Mediterranée. Vie Milieu 12:1-10

Zander CD (1996) The distribution and feeding ecology of smallsize epibenthic fish in the coastal Mediterranean Sea. In: Eleftheriou A, Ansell AD, Smith CJ (eds) Biology and ecology of shallow coastal waters. Olsen and Olsen, Fredensborg, pp 369-376

Zander CD, Nieder J (1997) Interspecific associations in Mediterranean fishes: feeding communities, cleaning symbiosis and cleaner mimics. Vie Milieu 47: 203-212

Zander CD, Meyer U, Schmidt A (1999) Cleaner fish symbiosis in European and Macronesian waters. In: Almada VC, Oliveira RF, Gonçalves EJ (eds) Behaviour and conservation of littoral fishes. Instituto Superior de Psicologia Aplicada, Lisboa, pp 397-422 